\title{
Seroepidemiology of leptospirosis and toxoplasmosis in equines in the northwest region of Paraná
}

\section{Soroepidemiologia da leptospirose e toxoplasmose em equinos da região noroeste do Paraná}

\author{
Filipe Corrêa Pachecoㄹ ; Maria Augusta Dorigan Bondezan ${ }^{1}$; Ulisses de Pádua \\ Pereira $^{2}$; Roberta Torres Chiderolli³; Lucienne Garcia Pretto-Giordano ${ }^{2}$; Italmar \\ Teodorico Navarro ${ }^{2}$; Juliana Silva de Oliveira ${ }^{4}$; Andressa Maria Rorato Nascimento \\ de Matos $^{4}$; Luciana Kazue Otutumi ${ }^{5}$; Daniela Dib Gonçalves ${ }^{5 *}$
}

\begin{abstract}
Leptospirosis and toxoplasmosis are diseases that may affect man and domestic and wild animals. They also have wide geographical distributions and thus cause large public health issues. The objective of the current study was to conduct leptospirosis and toxoplasmosis seroepidemiology in horses used for animal traction in small rural propertiesof the municipality of Umuarama, in northwest region of the state of Paraná, Brazil. Blood samples were collected from 312 horses from 87 small farms. Microscopic agglutination tests (MAT) and indirect immunofluorescence (IIF) analysis were performed on sera to detect leptospirosis and toxoplasmosis, respectively. These were performed in conjunction with an epidemiological questionnaire. The MAT results included 180 (57.69\%) samples that were considered reactive with titers between 100 and 12800 for one or more serovars. Thirty-three (10.57\%) samples subjected to IIF were considered reactive, with titers ranging between 64 and 1024. From the analyzed variables, contact with wild animals $(p=0.012)$ and animal exchange between properties $(p=0.004)$ were associated with toxoplasma infection. The study revealed that horses in the northwestern region of Paraná were exposed to Leptospira spp. and Toxoplasma gondii, with an insignificant implication of the animals' clinical condition; however, since it is possible for animals to transmit infection to other animals as well as humans via the intermittent shedding of leptospires through urine into the environment, it may be considered a problem of one health. As for the presence of $T$. gondii antibodies, these horses played the role of sentinel of the infection. Environmental sanitation measures, serological studies of herds, control of rodents and felids on properties, and the dissemination of information about these diseases are relevant for disease control at the study site.
\end{abstract}

Key words: Carters. Risk factors. Leptospira spp. Toxoplasma gondii. Zoonosis.

\footnotetext{
1 Discentes, Curso de Graduação em Medicina Veterinária, Universidade Paranaense, UNIPAR, Umuarama, PR, Brasil. E-mail: lypepacheco@hotmail.com; guta_dorigan10@hotmail.com

2 Pesquisadores, Departamento de Medicina Veterinária Preventiva, Universidade Estadual de Londrina, UEL, Londrina, PR, Brasil. E-mail: upaduapereira@gmail.com; luciennegiordano@gmail.com; italmar@uel.br

${ }^{3}$ Discente, Curso de Doutorado do Programa de Pós-Graduação em Ciência Animal, UEL, Londrina, PR, Brasil. E-mail: ro.vetuel@, gmail.com

4 Residentes, Laboratório deZoonoses e Saúde Pública, UEL, Londrina,PR, Brasil.E-mail:juoliv.vet@gmail.com; andressarorato@ gmail.com.br

5 Pesquisadoras, Programa de Pós-Graduação em Ciência Animal com Ênfase em Produtos Bioativos, Universidade Paranaense, UNIPAR, Umuarama, PR, Brasil.E-mail: otutumi@prof.unipar.br; danieladib@prof.unipar.br

* Author for correspondence
} 


\section{Resumo}

A leptospirose e a toxoplasmose são enfermidades de ampla distribuição geográfica e podem acometer o homem, animais domésticos e selvagens que causam elevados problemas para a saúde pública. $\mathrm{O}$ objetivo deste trabalho foi realizar a soroepidemiologia da leptospirose e toxoplasmose em equinos utilizados como tração animal de pequenas propriedades rurais do município de Umuarama, região noroeste do estado do Paraná, Brasil. Foram coletadas amostras de sangue de 312 equinos de 87 pequenas propriedades rurais. Para detectar a leptospirose e toxoplasmose os soros foram submetidos às técnicas de soroaglutinação microscópica (SAM) e imunofluorescencia indireta (IFI) respectivamente associada ao preenchimento de um questionário epidemiológico. Na SAM, 180 (57,69\%) amostras foram consideradas reagentes apresentando títulos entre 100 e 12800 , para um ou mais sorovares. Na IFI, $33(10,57 \%)$ amostras foram consideradas reagentes com títulos de 64 a 1024. Em relação às variáveis analisadas, o contato com animais selvagens $(\mathrm{p}=0,012)$ e troca de animais entre propriedades $(\mathrm{p}=0,004)$ foram associados à infecção toxoplásmica. O estudo revela que os equinos da região noroeste do Paraná estão expostos a Leptospira spp. e ao Toxoplasma gondii, tendo uma implicação insignificante relacionado ao aspecto clínico destes animais, porém podendo ser considerados um problema para a saúde única, pois, os animais possivelmente estão eliminando leptospiras pela urina de forma intermitente no meio ambiente podendo infectar outros animais e também o homem. Quanto à presença de anticorpos anti $T$. gondii estes equinos fizeram papel de sentinelas da infecção. Medidas de saneamento aplicadas ao meio ambiente, estudos sorológicos dos rebanhos, controle de roedores e felídeos das propriedades e a divulgação de informações sobre estas enfermidades são relevantes para o controle no local de estudo.

Palavras-chave: Carroceiros. Fatores de risco. Leptospira spp. Toxoplasma gondii. Zoonose.

\section{Introduction}

According to Instituto Brasileiro de Geografia e Estatística (IBGE), there are approximately 5.8 million horses in Brazil, which makes it the largest herd in Latin America and the third largest in the world, after China and Mexico, moving R\$ 7.3 billion/year (BRASIL, 2013). The herd of equines involves several segments, including the distribution of inputs, breeding, and their final destination, forming the basis of the so-called Horse Agribusiness Complex, responsible for generating 3.2 million direct and indirect jobs. Equidae have been used for many years solely as a means of transportation and in daily agricultural activities, mostly the management of the cattle herd. Recently, equidae have been involved in other areas of activity, such as leisure activities, sports, and even therapy (BRASIL, 2016).

Leptospirosis is a cosmopolitan geographic distribution anthropozoonosis that affects humans as well as domestic and wild animals. It is more prevalent in tropical and subtropical regions (ELLIS, 2015; FINGER et al., 2014) and is caused by different pathogenic leptospire species. It can be found in soil, water, and possibly infected animal reservoirs in urban and rural areas (FINGER et al., 2014; HASHIMOTO et al., 2007). Transmission may occur through exposure of the skin and/or mucous membranes to contaminated milk, water, or food, as well as through infected urine, placental fluids, semen, and vaginal discharge (BATISTA et al., 2015; ELLIS, 2015; RODRIGUEZ et al., 2017).

In horses, Leptospira spp. infections may show acute or chronic manifestations; however, most cases present with non-specific symptoms, which makes the disease difficult to diagnose. Recurrent uveitis, abortion, and other reproductive disorders have been reported by several authors (ELLIS, 2015; LINHARES et al., 2005; WITKOWSKI et al., 2016). 
Toxoplasmosis is considered one of the most common parasitic infections worldwide, and is a zoonosis that has aroused great interest in the fields of veterinary medicine and public health (VASCONCELOS, 2003). It is caused by Toxoplasma gondii, a protozoan that is an obligate intracellular parasite. Its definitive hosts are wild and/or domestic felines (CAÑÓN-FRANCO et al., 2013; FIALHO et al., 2009; VENTURI et al., 2017).

In horses, transmission occurs through the ingestion of food, such as grass, hay, and feed that has been contaminated by sporulatedoocysts. In carnivores and humans, the infection occurs via the ingestion of raw or undercooked meat containing $T$. gondii tissue cysts (ELLIS, 2015). Equines are most resistant to infection by this parasite among all the domestic species. Although rare, they may present some clinical neurological signs characterized by hyperirritability, motor incoordination, and ocular disorders, as well as reproductive clinical signs such as infertility and abortion. In most cases, $T$. gondii causes sub-clinical manifestations and sporadic abortions (ABREU, 2013).

Both diseases present with nonspecific symptoms and are difficult to diagnose clinically; thus, the support of the serological techniques for the detection of antibodies against Leptospira spp. and $T$. gondii to confirm the diagnosis is essential (CAMOSSI et al., 2010; FAINE et al., 1999). The objective of the present work was to conduct leptospirosis and toxoplasmosis seroepidemiology in horses used for animal traction in small rural properties of the municipality of Umuarama, in northwest region of the state of Paraná, Brazil.

\section{Materials and Methods}

\section{Sampling, study sample and location}

Considering the size of the population of 2070 equines according to IPARDES (2019) for the year 2017 for the municipality of Umuarama, Paraná and the expected prevalence of $50 \%$, error of $6 \%$ and level of significance of $6 \%$ were used, obtaining an ideal number of 252 horses, according to the formula described by Barbetta (1999).

$$
\begin{aligned}
& \mathrm{n}_{0}=1 / \mathrm{E}_{0}^{2} \\
& \mathrm{n}=\mathrm{N} \cdot \mathrm{n}_{0} /\left(\mathrm{N}+\mathrm{n}_{0}\right)
\end{aligned}
$$

At where:

$$
\begin{aligned}
& N=\text { population size }(2654) ; \\
& E_{0}=\text { tolerable sample error }=6 \% ; \\
& n_{0}=\text { first approximation of the sample size; } \\
& n=\text { sample size. }
\end{aligned}
$$

Blood samples were collected in the period between March and September 2016 from 312 crossbred horses, used for animal traction in small rural properties of the municipality of Umuarama, in northwest region of the state of Paraná, Brazil, that were at reproductive age (18 months of age or older) and did not show clinical signs of any disease.

Blood collection was performed through jugular vein puncture by veterinarians and students of the veterinary medicine course at Paranaense University (UNIPAR). Approximately $10 \mathrm{~mL}$ of blood was collected and stored in sterile tubes without anticoagulant, placed in isothermal boxes, and subsequently sent to the Laboratory of Preventive Veterinarian Medicine of the Graduate Program in Animal Science with Emphasis on Bioactive Products of the Paranaense University (UNIPAR). In the laboratory, samples were centrifuged to obtain the serum, equally divided into three aliquots, and stored in sterile bottles at $-20^{\circ} \mathrm{C}$.

\section{Diagnostics performed}

To detect anti-Leptospira spp., sera were subjected to the microscopic agglutination test (MAT) with live antigens (FAINE et al., 1999) at the Laboratory of Leptospirosis of the Department of Preventive Veterinary Medicine (DPVM) of the State University of Londrina (UEL). The following 
22 reference serovars were used: Australis, Bratislava, Autumnalis, Fortbragg, Castellonis, Bataviae, Canicola, Whitcombi, Cynopteri, Grippotyphosa, Hebdomadis, Copenhageni, Icterohaemorrhagiae, Panama, Pomona, Pyrogenes, Hardjo, Wolffi, SentotTarassovi,andShermani. Antigens were maintained at $28^{\circ} \mathrm{C}$ for five to 10 days in Difco ${ }^{\mathrm{TM}}$ Leptospira Enrichment (EMJH) medium (DIFCO $\left.{ }^{\circledR}-U S A\right)$, modified by the addition of rabbit serum (ALVES et al., 1996). A 1:100 dilution was used as the cut-off point (MYERS, 1985).

Serum containing at least $50 \%$ of agglutinated leptospires were considered reactive and were subsequently geometrically diluted in ratio two to determine the maximum positive dilution. In the analysis of the results, the most-probable serovar was that with the highest titer (VASCONCELLOS et al., 1997). The sera that coagglutinated at the highest dilution were considered only reactive for Leptospira spp. (ALMEIDA et al., 1994).

To detect anti- $T$. gondii antibodies, sera were assessed using the indirect immunofluorescence test (IIF) (CAMARGO, 1974) with commercial antiBovine IgG conjugate (FITC - Sigma ${ }^{\circledR}$, USA) at the Zoonoses and Public Health Laboratory of the State University of Londrina (UEL). Sera were tested in sequential base four dilutions up to 1: 4096. Those with a fluorescent tachyzoites at a titer $\geq 16$ were considered reactive.

\section{Research Instrument}

To detect the variables associated with leptospirosis and toxoplasmosis, property owners were interviewed, who responded to an epidemiological questionnaire that contained information on the following: animal age, vaccination, feeding, sharing of water with other animals, exchange of animals between farms, veterinary assistance, presence of reproductive problems, presence of wild animals on the property, and presence of felines and rodents on the property, among others.

\section{Statistical analysis}

The results obtained after the study of the variables associated with the presence of Leptospira spp. and $T$. gondii infections were statistically analyzed via the chi-square test $\left(\mathrm{x}^{2}\right)$ with Yates correction or Fisher's exact test and a 5\% significance level using SPSS statistical software, v. 21.0.

\section{Results}

Samples were collected from 312 horses used for animal traction in 87 small farms (118 [37.82\%] male and 194 [62.18\%] female horses).

The MAT revealed that $180(57.69 \%)$ animals from $70(80.46 \%)$ properties were considered reactive for leptospirosis $(37.22 \%$ male and $62.78 \%$ female). Antibodies against the most probable serovars detected were as follows: Ichterohaemorrhagiae, with 68 (50.37\%) samples; Butembo, with 19 (14.07\%); Pomona, with nine (6.67\%); Canicola and Hardjo, with seven (5.18\%) each; Grippotyphosa, Australis and Wolffi with five (3.70\%) each; Copenhageni, with three (2.23\%); Bratislava, with two (1.48\%); and Castellonis, Panama, Pyrogenes, Sentot,andTarassoviwith one $(0.74 \%)$ each. Titers ranged between 100 and 12800 (Table 1). It was not possible to identify the most probable serovar in $45(25 \%)$ animals, which were thus considered only reactive for Leptospira spp. There were no variables associated with leptospirosis infection. 
Table 1. Most probable serovars and titers detected in microscopic serum agglutination (MAT) for leptospirosis in 135 seroreactive samples of equine of traction from 70 small rural properties of the municipality of Umuarama, in northwest region of the state of Paraná, Brazil, 2016.

\begin{tabular}{ccccccccc}
\hline & \multicolumn{7}{c}{ Serological Titers } \\
\hline Most likely serovars & 100 & 200 & 400 & 800 & 1.600 & 3.200 & 12.800 & Total (\%) \\
\hline Icterohaemorrhagiae & 21 & 31 & 11 & 5 & - & - & - & $68(50.37)$ \\
Butembo & 7 & 7 & 5 & - & - & - & - & $19(14.07)$ \\
Pomona & 2 & 3 & 2 & 2 & - & - & - & $9(6.67)$ \\
Canicola & 1 & 1 & 3 & 1 & 1 & - & - & $7(5.18)$ \\
Hardjo & 2 & 2 & - & 1 & - & 1 & 1 & $7(5.18)$ \\
Grippotyphosa & 1 & 3 & - & - & 1 & - & - & $5(3.70)$ \\
Australis & 2 & 4 & - & - & - & - & - & $5(3.70)$ \\
Wolffi & - & 2 & 1 & - & 2 & - & - & $5(3.70)$ \\
Copenhageni & - & 3 & - & - & - & - & - & $3(2.23)$ \\
Bratislava & 1 & 1 & - & - & - & - & - & $2(1.48)$ \\
Panama & 1 & - & - & - & - & - & - & $1(0.75)$ \\
Castellonis & - & - & - & - & - & - & - & $1(0.75)$ \\
Pyrogenes & - & - & - & - & 1 & - & - & $1(0.75)$ \\
Tarassovi & - & - & 1 & - & - & - & - & $1(0.75)$ \\
Sentot & - & - & 1 & - & - & - & - & $1(0.75)$ \\
\hline Total & 38 & 57 & 24 & 9 & 5 & 1 & 1 & $135(100)$ \\
\hline
\end{tabular}

*It was not possible to identify the most probable serovar in $45(25 \%)$ animals, which are thus considered only as reactive against Leptospira spp.

For toxoplasmosis, 33 samples $(10.58 \%$, of reactive in the IIF analysis, with titers ranging from which $63.63 \%$ were male and $36.37 \%$ were female) 64 to 1024 (Table 2).

from $25(28.73 \%)$ properties were considered

Table 2. Anti-Toxoplasma gondii antibody titers detected via indirect immunofluorescence (IIF) in 33 seroreactive samples from equine of traction from 25 small rural properties of the municipality of Umuarama, in northwest region of the state of Paraná, Brazil, 2016.

\begin{tabular}{|c|c|c|c|}
\hline \multirow{2}{*}{ Antibody titers } & \multicolumn{2}{|c|}{ Frequency } & \multirow{2}{*}{ Total (\%) } \\
\hline & Female & Male & \\
\hline 64 & 20 & 8 & $28(84.8)$ \\
\hline 256 & 0 & 3 & $3(9.10)$ \\
\hline 1024 & 1 & 1 & $2(6.10)$ \\
\hline Total (\%) & $21(63.63)$ & $12(36.37)$ & $33(100)$ \\
\hline
\end{tabular}

There were no variables associated with leptospirosis infection (Table 3). 
Table 3. Analyzed variables for Leptospira spp. of the equine of traction from 87 small rural properties of the municipality of Umuarama, in the northwest region of the state of Paraná, Brazil, 2016.

\begin{tabular}{|c|c|c|c|}
\hline Variable & Total Positivity (\%) & $\mathbf{P}$ & OR (CI 95\%) \\
\hline \multicolumn{4}{|l|}{ Vaccinated against leptospirosis } \\
\hline Yes & $3 / 3(100 \%)$ & \multirow{2}{*}{$1.000^{*}$} & \multirow{2}{*}{$\begin{array}{c}0.957 \\
(0.911-1.006)\end{array}$} \\
\hline No & $67 / 84(79.8 \%)$ & & \\
\hline \multicolumn{4}{|l|}{ Feed Exposed to the Environment } \\
\hline Yes & $2 / 4(50.0 \%)$ & \multirow{2}{*}{$0.170 *$} & \multirow{2}{*}{$\begin{array}{c}0.2206 \\
(0.0287-1.6934)\end{array}$} \\
\hline No & $68 / 83(81.9 \%)$ & & \\
\hline \multicolumn{4}{|l|}{$\underline{\text { Contact with Wild Animals }}$} \\
\hline Yes & $20 / 25(80.0 \%)$ & \multirow{2}{*}{$1.000^{*}$} & \multirow{2}{*}{$\begin{array}{c}0.960 \\
(0.299-3.078)\end{array}$} \\
\hline No & $50 / 62(80.6 \%)$ & & \\
\hline \multicolumn{4}{|l|}{ Shared water source } \\
\hline Yes & $46 / 57(80.7 \%)$ & \multirow{2}{*}{$0.937 * *$} & \multirow{2}{*}{$\begin{array}{c}1.045 \\
(0.344-3.174)\end{array}$} \\
\hline No & $24 / 30(80.0 \%)$ & & \\
\hline \multicolumn{4}{|c|}{ Exchange of animals between properties } \\
\hline Yes & $22 / 26(84.6 \%)$ & \multirow{2}{*}{$0.523 * *$} & \multirow{2}{*}{$\begin{array}{c}1.490 \\
(0.436-5.091)\end{array}$} \\
\hline No & $48 / 61(78.7 \%)$ & & \\
\hline \multicolumn{4}{|l|}{ Presence of Reproductive Problems } \\
\hline Yes & $6 / 6(100 \%)$ & \multirow{2}{*}{$0.3456^{*}$} & \multirow{2}{*}{-} \\
\hline Not known & $64 / 81(79.0 \%)$ & & \\
\hline \multicolumn{4}{|l|}{ Veterinary care } \\
\hline Yes & $28 / 34(82.4 \%)$ & \multirow{2}{*}{$0.721 * *$} & \multirow{2}{*}{$\begin{array}{c}1.222 \\
(0.405-3.685)\end{array}$} \\
\hline No & $42 / 53(79.2 \%)$ & & \\
\hline \multicolumn{4}{|c|}{ Contact with Horses from Other Properties } \\
\hline Yes & $34 / 43(79.1 \%)$ & \multirow{2}{*}{$0.747 * *$} & \multirow{2}{*}{$\begin{array}{c}0.840 \\
(0.290-2.427)\end{array}$} \\
\hline No & $36 / 44(81.8 \%)$ & & \\
\hline \multicolumn{4}{|l|}{ Contact with other species } \\
\hline Yes & $64 / 81(79.0 \%)$ & \multirow{2}{*}{$0.593 *$} & \multirow{2}{*}{-} \\
\hline No & $6 / 6(100 \%)$ & & \\
\hline \multicolumn{4}{|l|}{$\underline{\text { Presence of rodents }}$} \\
\hline Yes - currently or in the past & $56 / 69(81.2 \%)$ & \multirow{3}{*}{$0.745^{*}$} & \multirow{3}{*}{$\begin{array}{c}1.231 \\
(0.348-4.358)\end{array}$} \\
\hline Yes & $14 / 18(77.8 \%)$ & & \\
\hline No & $50 / 64(78.1 \%)$ & & \\
\hline
\end{tabular}

$\mathrm{P}=$ probability; * Fisher's Exact Test; ** Chi-square with Yates correction; $\mathrm{OR}=$ Odds Ratio; $\mathrm{CI}=$ Confidence Interval.

Regarding the analyzed variables, contact with between properties $(p=0.004)$ were associated with wild animals $(\mathrm{p}=0.012)$ and animal exchange T.gondii infection (Table 4). 
Table 4. Analyzed variables for Toxoplasma gondiiof the equine of traction from 87 small rural of the municipality of Umuarama, in northwest region of the state of Paraná, Brazil, 2016.

\begin{tabular}{|c|c|c|c|}
\hline Variable & Total Positivity (\%) & $\mathbf{P}$ & OR (CI 95\%) \\
\hline \multicolumn{4}{|c|}{ Feed Exposed to the Environment } \\
\hline Yes & $1 / 4(25 \%)$ & \multirow{2}{*}{$1.000^{*}$} & \multirow{2}{*}{$\begin{array}{c}0.819 \\
(0.081-8.275)\end{array}$} \\
\hline No & $24 / 83(28.9 \%)$ & & \\
\hline \multicolumn{4}{|c|}{$\underline{\text { Contact with Wild Animals }}$} \\
\hline Yes & $12 / 25(48 \%)$ & \multirow{2}{*}{$0.012 * *$} & \multirow{2}{*}{$\begin{array}{c}3.479 \\
(1.287-9.408)\end{array}$} \\
\hline No & $13 / 62(20.9 \%)$ & & \\
\hline \multicolumn{4}{|c|}{$\underline{\text { Shared water source }}$} \\
\hline Yes & $16 / 57(28.1 \%)$ & \multirow{2}{*}{$0.850^{* *}$} & \multirow{2}{*}{$\begin{array}{c}0.911 \\
(0.345-2.405)\end{array}$} \\
\hline No & $9 / 30(30 \%)$ & & \\
\hline \multicolumn{4}{|c|}{ Exchange of animals between properties } \\
\hline Yes & $13 / 26(50 \%)$ & \multirow{2}{*}{$0.004 * *$} & \multirow{2}{*}{$\begin{array}{c}4.083 \\
(1.510-11.041)\end{array}$} \\
\hline No & $12 / 61(19.7 \%)$ & & \\
\hline \multicolumn{4}{|c|}{ Frequency of Reproductive Problems } \\
\hline First & $2 / 5(40 \%)$ & \multirow{2}{*}{$0.623^{*}$} & \multirow{2}{*}{$\begin{array}{c}1.710 \\
(0.268-10.908)\end{array}$} \\
\hline Not known & $23 / 82(28 \%)$ & & \\
\hline \multicolumn{4}{|c|}{$\underline{\text { Veterinary care }}$} \\
\hline Yes & $11 / 34(32.3 \%)$ & \multirow{2}{*}{$0.550 * *$} & \multirow{2}{*}{$\begin{array}{c}1.332 \\
(0.519-3.421)\end{array}$} \\
\hline No & $14 / 53(26.4 \%)$ & & \\
\hline \multicolumn{4}{|c|}{ Contact with Horses from Other Properties } \\
\hline Yes & $15 / 43(34.9 \%)$ & \multirow{2}{*}{$0.210^{* *}$} & \multirow{2}{*}{$\begin{array}{c}1.821 \\
(0.709-4.680)\end{array}$} \\
\hline No & $10 / 44(22.7 \%)$ & & \\
\hline \multicolumn{4}{|c|}{$\underline{\text { Contact with other species }}$} \\
\hline Yes & $24 / 81(29.6 \%)$ & \multirow{2}{*}{$0.669^{*}$} & \multirow{2}{*}{$\begin{array}{c}2.105 \\
(0.233-18.988)\end{array}$} \\
\hline No & $1 / 6(16.7 \%)$ & & \\
\hline
\end{tabular}

$\mathrm{P}=$ probability; * Fisher's Exact Test; ** Chi-square with Yates correction; OR = Odds Ratio; CI = Confidence Interval.

Regarding the 87 rural properties studied, 70 $(80.46 \%)$ and $25(28.73 \%)$ presented at least one animal deemed reactive by MAT against leptospirosis and reactive by IIF against toxoplasmosis, respectively. Of the studied properties, 24 (27.59\%) presented reactive animals for both diseases, while $16(18.39 \%)$ were considered negative for both infections.

\section{Discussion}

Unlike other segments of the Brazilian economy, agribusiness has grown in recent years; within this context, animal creation aimed at the urban public, both for leisure activities and for sports, has experienced strong growth. Unlike work animals, usually associated with cattle, horses involved in sports or recreational activities require greater care and investment. However, working animals still account for $80 \%$ of the national troop. The denominated Horse Agribusiness complex employs 607.329 people directly and, taking into consideration the fact that each direct job generates four other indirect jobs, one estimates that $2.429,316$ jobs are generated. Thus, the Complex is responsible, directly and indirectly, for three million 
employment opportunities (BRASIL, 2016).

There are different serological studies available in the literature with equines used for animal traction in urban areas. The majority describe a high prevalence of leptospirosis that is related to problems with the infrastructure and basic sanitation, in conjunction with the presence of rodents (DIAS et al., 2015; FINGER et al., 2014; LASTA et al., 2013). Studies involving equines used for animal traction in rural areas are scarcer, possibly due to the distance and difficulty in the required travel from one property to another. Thus, research under this setting becomes important, considering that the rural epidemiology of leptospirosis is quite different from the urban one.

In the present work, MAT revealed that $57.69 \%$ of animals were reactive against leptospirosis. Similar results were described by Silva et al. (2015) in the states of Mato Grosso do Sul (MS), Mato Grosso (MT), Ceará (CE), Pernambuco (PE), and Bahia (BA) and by Pinna et al. (2008) in Rio de Janeiro (RJ), where they detected $52.63 \%$ and $55.40 \%$ of MAT seroreactive animals, respectively; lower results $(28 \%)$ were detected by Alves et al. (2016) in Pajeú (PE) using the same test. These serological results may have been influenced by the differences in the prevalence of animal leptospirosis in their respective locations, in addition to being a reflection of the study periods, which may have enhanced or decreased the probabilities of infection occurring in these equines.

In rural areas, Ellis (2015) stated that the central point of leptospirosis is the renal carrier excreting leptospires into the environment; the author also noted that sexual transmission is important in intraspecies transmission. Keeping infectioncarrying equines and other species in contact with the equine herd may pose an important risk factor.

According to Ellis (2015), the infected, asymptomatic equines can excrete viable leptospires intermittently over long periods of time through the urine. This makes this animal species an important reservoir of the disease, rendering it a health problem, since environmental contamination and consequently the infection of man and other animals can occur.

Icterohaemorrhagiae was the most (50.37\%) prevalent of the assessed serovars in the present study; similar results (42\%) were also detected by Gomes et al. (2007) in Bahia, Brazil. Icterohaemorrhagiae is considered one of the leptospirosis serovars of major clinical importance, since most of the animals present with clinical symptoms suggestive of leptospirosis, such as abortions, renal failure, and uveitis. In the vast majority of cases, the infection is associated with rodents (ADLER; MOCTEZUMA, 2010; BATISTA et al., 2015). In the current study, this detection can be justified by the fact that $79.30 \%$ of the rural properties reported the presence of rodents, which is the main reservoir of this serovar.

MAT antibody titers ranged between 100 and 12800 in the current study. This suggests the presence of possible chronic and acute infections and late and recent exposures to Leptospira spp. However, no animal at the time of blood collection showed any clinical manifestations, which is consistent with the work of Linhares et al. (2005) and Hashimoto et al. (2007) in Goiânia (GO) and Londrina (PR), respectively. It is worth emphasizing that the infections detected by MAT are all (100\%) due to natural infections, with no chance of arising from residual vaccination titers, as evidenced by the farmers' answers on the epidemiological questionnaire about animal vaccination.

The analyzed variables did not show association with leptospiral infection. This disagrees with the work by Alves et al. (2016) in Pernambuco, where pasture, the main food source, was considered a risk factor, stemming from the fact that natural reservoirs of the disease may be excreting the agent into the environment. Fodder, which is the main food source for animals in this region, originates from swampy areas, which does not cause great concern since in the region of the current study, the soil is sandy and 
well-drained, hindering the formation of wetlands.

Although horses are among the domestic species most resistant to Toxoplasma gondii, recent studies show an increase in infections in the recent years, with a significant and widespread prevalence, varying between $10 \%$ and $28 \%$ throughout the country (GENNARI et al., 2015; MOURA et al., 2016; VALENÇA et al., 2015). Regarding the 87 rural properties in this study, $25(28.73 \%)$ had at least one animal reactive against toxoplasmosis by IIF, a value below that found by Valença et al. (2015) in Alagoas (AL), where $69.40 \%$ of the studied properties had MAT-reactive animals.

In the current study, $10.57 \%$ of the animals were seroreactive in IIF, similar to the results found by Moura et al. (2016) in Santa Catarina (SC) and Valença et al. (2015) in Alagoas (AL), with a prevalence of $10.40 \%$ and $14.30 \%$, respectively. In the literature, there are also reports of higher prevalence in Minas Gerais (MG) (GENNARI et al., 2015) and Italy (PAPINI et al., 2015). However, work performed in Mato Grosso (MT) detected antibodies in only $2.5 \%$ of the equines surveyed (LASKOSKI et al., 2015). Since the transmission of this disease occurs only by elimination of the etiological agent into the environment through felids' feces, with equines considered as infection sentinels only, this difference is influenced by the differences in the prevalence of toxoplasmosis in felids (domestic or wild) at the respective study sites.

Different diagnostic techniques, cut-off values, geographic locations, and management conditions may partially explain some of the differences in prevalence found in the literature (FINGER et al., 2013; VENTURI et al., 2017). In the present study, a IIF antibody titer cut-off value of 64 was considered an infection, which is consistent with previous studies (GENNARI et al., 2015; MOURA et al., 2016; PAPINI et al., 2015; VALENÇA et al., 2015). This value guarantees greater specificity, in addition to decreasing the possibility of cross-reactions with other etiological agents (ABREU, 2013).

Regarding the analyzed variables, animal exchange between properties $(p=0.004)$ was associated with infection in the present study, which may indicate exposure to the etiologic agent at a given time of these animals' lives, as well as a sign of possible infected felines in the premises.

Contact with wild animals $(\mathrm{p}=0.012)$ was also associated with $T$. gondii infection. According to Cañón-Franco et al. (2013), the presence of wild felids can be considered a risk factor for toxoplasmosis transmission, justifying the prevalence found in the current study, wherein producers reported the presence of small wild felids in the studied properties.

Since domestic cats were observed in many rural properties during the study, it is important to emphasize that the presence of cats in several of the studied properties may have influenced the positivity of their respective animals. According to Rizzo et al. (2017), the risk of infection in places where felines are present increases 1.37 times. On the other hand, Valença et al. (2015) and AlvaradoEsquivel et al. (2012) found that providing animals with hay and feed, instead of allowing them to graze, is a risk factor worthy of investigation and care on felines accessing that hay.

\section{Conclusion}

The study reveals that horses in small rural properties of the municipality of Umuarama, in northwest region of the state of Paraná are exposed to Leptospira spp. and Toxoplasma gondii, with an insignificant implication of their clinical aspect. However, since animals are possibly intermittently excreting leptospires through their urine into the environment, with the ability to infect other animals and man, it may be considered problematic for an individual's health. As for the presence of T. gondii antibodies, these horses played the role of sentinel of the infection. Environmental sanitation measures, 
serological studies of herds, control of rodents and felids on properties, and the dissemination of information about these diseases are relevant for disease control at the study site.

\section{Ethics Committee}

This project was submitted to the Ethics Committee on Animal Experimentation (CEPEEA) of UNIPAR and was approved under protocol $30306 / 2016$ on $12 / 03 / 2015$.

\section{Acknowledgments}

We would like to acknowledge the owners for their constant collaboration and UNIPAR for the funding granted for this research.

\section{References}

ABREU, R. A. Diagnóstico sorológico de Neosporasp. e Toxoplasma gondii e sua investigação no sêmen de garanhões em propriedades com falhas reprodutivas em éguas. 2013. Dissertação (Engenharia de Bioprocessos e Biotecnologia, Área de Concentração: Saúde Animal e Humana) - Setor de Tecnologia, Universidade Federal do Paraná, Curitiba.

ADLER, B.; MOCTEZUMA, A. P. Leptospira and leptospirosis. Veterinary Microbiology, Amsterdam, v. 140, n. 3, p. 287-296, 2010.

ALMEIDA, L. P.; SILVA MARTINS, L. F. da; BROD, C. S.; GERMANO, P. M. L. Levantamento soroepidemiológico de leptospirose em trabalhadores do serviço de saneamento ambiental em localidade urbana da região sul do Brasil. Revista de Saúde Pública, São Paulo, v. 28, n. 1, p. 76- 81, 1994.

ALVARADO-ESQUIVEL， C.; RODRÍGUEZ-PEÑA, S.; VILLENA, I.; DUBEY, J. P. Seroprevalence of Toxoplasma gondii infection in domestic horses in Durango State, Mexico. Journal of Parasitology, Indianapolis, v. 98, n. 5, p. 944-945, 2012.

ALVES, C. J.; VASCONCELLOS, S. A.; CAMARGO, C. R. A.; MORAIS, Z. M. Influência de fatores ambientais sobre a proporção de caprinos soro reatores para a leptospirose em cinco centros de criação do estado da Paraíba, Brasil. Arquivos do Instituto Biológico, São Paulo, v. 63, n. 2, p. 11-18, 1996.
ALVES, J. R. A.; OLIVEIRA, K. D. S. D.; COSTA, D. F. D.; FERNANDES, L. G.; HIGINO, S. S. D. S.; ALVES, C. J.; SANTOS, C. S. A. B.; AZEVEDO, S. S. D. Epidemiological characterization of leptospirosis in horses in the state of Pernambuco, northeastern Brazil. Arquivos do Instituto Biológico, São Paulo, v. 83, n. 1, p. 1-5, 2016.

BARBETTA, P. A. Estatística aplicada às ciências sociais. 3. ed. Florianópolis: UFSC, 1999. 283 p.

BATISTA, J. S.; PAIVA, C. C. P. L.; SILVA, J. B.; COSTA, A. M.; CAVALCANTE, P. H.; PRAÇA, L. M.; OLINDA, R. G.; PAIVA, K. A. R. Avaliação de cinco casos de abortamento associado à leptospirose em éguas no Rio Grande do Norte. Revista Brasileira de Ciência Veterinária, Niterói, v. 22, n. 3-4, p. 165-170, 2015.

BRASIL. Instituto Brasileiro de Geografia e Estatística (IBGE). Produção da Pecuária Municipal. Rio de Janeiro: Ministério do Planejamento, Orçamento e Gestão, 2013. v. 41, p. 1-108. Disponível em: <https:// goo.gl/ok9WYM>. Acesso em: 11 nov. 2016.

BRASIL. Ministério da Agricultura, Pecuária e Abastecimento. Revisão do Estudo do Complexo do Agronegócio do Cavalo. Brasília: Ministério da Agricultura, Pecuária e Abastecimento, 2016. Disponível em: <https://goo.gl/K71uUo>. Acesso em: 11 nov. 2016.

CAMARGO, M. E. Introdução às técnicas de imunofluorescência. Revista Brasileira de Patologia Clínica, São Paulo, v. 10, n. 4, p. 143-171, 1974.

CAMOSSI, L. G.; SILVA, A. V.; LANGONI, H. Inquérito sorológico para toxoplasmose em equinos na região de Botucatu-SP. Arquivo Brasileiro de Medicina Veterinária e Zootecnia, Belo Horizonte, v. 62, n. 2, p. 484-488, 2010.

CAÑÓN-FRANCO, W. A.; ARAÚJO, F. A. P.; GENNARI, S. M. Toxoplasma gondii in small neotropical wild felids. Brazilian Journal of Veterinary Research and Animal Science, São Paulo, v. 50, n. 1, p. 50-67, 2013.

DIAS, H. L. T.; SANTOS, W. R. R.; SANTOS, C.V.; LIMA, P. D. L. de; NEGAO, A. M. G.; VASCONCELLOS, S. A. Inquérito sorológico para leptospirose em condutores de carroças e equídeos de tração em Belém, Pará. Revista de Ciências Agrárias, Belém, v. 58, n. 4, p. 396-401, 2015.

ELLIS, W. A. Animal leptospirosis. Current Topics in Microbiology and Immunology, Londres, v. 387, n. 1, p. 99-137, 2015.

FAINE, S.; ADLER, B.; BOLIN, C.; PEROLAT, P. Leptospira and Leptospirosis. $2^{\text {th }}$ ed. Melbourne: MedSci, 1999. $272 \mathrm{p}$. 
FIALHO, C. G.; TEIXEIRA, M. C.; ARAUJO, F. A. P. Toxoplasmose animal no Brasil. Acta Scientiae Veterinariae, Porto Alegre, v. 37, n. 1, p. 1-23, 2009.

FINGER, M. A.; BARROS-FILHO, I. R.; LEUTENEGGER, C.; ULLMANN, L. S.; LANGONI, H.; KIKUTI, M.; DORNBUSH, P. T.; DECONTO, I.; BIONDO, A. W. Serological and molecular survey of Leptospira spp. among cart horses from an endemic area of human leptospirosis in Curitiba, Southern Brazil. Revista do Instituto de Medicina Tropical de São Paulo, São Paulo, v. 56, n. 6, p. 473-476, 2014.

FINGER, M. A.; VILLALOBO, E. M. C.; LARA, M. C. C. S. H.; CUNHA, E. M. S.; BARROS-FILHO, I. R.; DECONTO, I.; DORNBUSH, P. T.; ULLMANN, L. S.; BIONDO, A. W. Detection of anti-Toxoplasma gondii antibodies in carthorses in the metropolitan region of Curitiba, Paraná, Brazil. Revista Brasileira de Parasitologia Veterinária, Jaboticabal, v. 22, n. 1, p. 179181, 2013.

GENNARI, S. M.; ESMERINI, P. O.; LOPES, M. G.; SOARES, H. S.; VITALIANO, S. N.; CABRAL, A. D.; PENA, H. F. J.; HORTA, M. C.; CAVALCANTE, P. H.; FORTES, K. P.; VILLALOBOS, E. M. C. Occurrence of antibodies against Toxoplasma gondii and its isolation and genotyping in donkeys, mules, and horses in Brazil. Veterinary Parasitology, Indianapolis, v. 209, n. 1, p. 129-132, 2015.

GOMES, A. H. B.; OLIVEIRA, F. C. S.; CAVALCANTI, L.A.; CONCEICAO, I. R.; SANTOS, G. R.; RAMALHO, E. J.; VIEGAS, S. A. R. A. Ocorrência de aglutininas anti-Leptospiraem soro de equinos no estado da Bahia. Revista Brasileira Saúde Produção Animal, Salvador, v. 8, n. 3, p. 144-151, 2007.

HASHIMOTO, V. Y.; GONCALVES, D. D.; SILVA, F. G.; OLIVEIRA, R. C.; ALVES, L. A.; REICHMANN, P.; MULLER, E. E.; FREITAS, J. C. Occurrence of antibodies against Leptospira spp. in horses of the urban area of Londrina, Paraná, Brazil. Revista do Instituto de Medicina Tropical de São Paulo, São Paulo, v. 49, n. 5, p. 327-330, 2007.

IPARDES. Caderno Estatístico do Município de Umuarama, 2019. Disponível em: <http:// www.ipardes.gov.br/cadernos/MontaCadPdf1. php?Municipio=87500>. Acesso em 11 fev 2019.

LASKOSKI, L. M.; MURARO, L. S.; DITTRICH, R. L.;ABREU, R. A.; KOCH, M. O.; SILVA, F. T.; HAGI, R. H. Occurrence of anti-Neospora caninum and antiToxoplasma gondii antibodies in horses in the Pantanal of Mato Grosso, Brazil. Semina: Ciências Agrárias, Londrina, v. 36, n. 2, p. 895-900, 2015.
LASTA, C. S.; OLIVEIRA, S. T.; MERINI, L. P.; DASSO, M. G.; PEDRALLI, V.; GONZALEZ, F. H. D. Pesquisa de aglutininas anti-Leptospira em soros de equinos de tração em Porto Alegre, Brasil. Revista Brasileira de Ciência Veterinária, Niterói, v. 20, n. 1, p. 23-25, 2013.

LINHARES, G. F. C.; GIRIO, R. J. S.; LINHARES, D. C. L.; MONDEIRO, L. C.; OLIVEIRA, A. P. Á. Sorovares de Leptospira interrogans e respectivas prevalências em cavalos da microrregião de Goiânia, GO. Ciência Animal Brasileira, Goiânia, v. 6, n. 4, p. 255-259, 2005.

MOURA, A. B.; MATIEllo, J. P.; SIlVA, M. O.; SOUSA, A. P.; SARTOR, A. A. Toxoplasma gondii in horses from the coastal and mountain mesoregions of the state of Santa Catarina, Brazil. Semina: Ciências Agrárias, Londrina, v. 37, n. 1, p. 203-212, 2016.

MYERS, D. Leptospirosis: manual de métodos para el diagnostico de laboratório. Centro Panamericano de Zoonoses. Buenos Aires: Organização Mundial da Saúde, 1985. 46 p. (Nota Técnica, 30).

PAPINI, R. A.; PAPINI, R. A.; BUZZONE, G.; NARDONI, S.; ROCCHIGIANI, G.; MANCIANTI, F. Seroprevalence and genotyping of Toxoplasma gondii in horses slaughtered for human consumption in Italy. Journal of Equine Veterinary Science, Nova Iorque, v. 35 , n. 8, p. 657-661, 2015.

PINNA, M. H.; VARGES, R.; LILENBAUM, W. Aplicação de um programa integrado de controle da leptospirose em equinos no Rio de Janeiro, Brasil. Revista Brasileira de Ciência Veterinária, Niterói, v. 15, n. 2, p. 63-66, 2008.

RIZZO, H.; GAETA, N.C.; HORA, J.H.C.; CARVALHO, J. S.; PINHEIRO-JUNIOR, J. W.; GENNARI, S. M.; PENA, H. F. J.; VILLASLOBO, E. M. C.; GREGORY, L. Fatores de risco para a infecção de Toxoplasma gondii em ovinos da região nordeste do Brasil. Brazilian Journal of Veterinary Research and Animal Science, São Paulo, v. 54, n. 2, p. 139-146, 2017.

RODRIGUEZ, G.; PINEROS, R.; PRADA, G.; DIAZ, C.; VENEGAS, C.; SALAZAR, C.; TRUJILlO, C.; NOSSA, L. C. Molecular determination of Leptospira spp. in semen and pre-ejaculatory fluid, and serological study of Creole horses in the department of Cundinamarca (Colombia). Revista de Medicina Veterinária, Bogotá, v. 34, p. 93-100, 2017. Supplement 1.

SILVA, F. J.; SANTOS, C. E. P.; SILVA, T. R.; SILVA, G. C. P.; LOFFER, S. G.; BRIHUEGA, B.; ALARCON, M. F. F.; CURCI, V. C. M.; MATHIAS, L. A. Pesquisa de leptospiras e de anticorpos contra leptospiras em animais e humanos de propriedades rurais nos biomas brasileiros 
Pantanal e Caatinga. Brazilian Journal of Veterinary Research and Animal Science, São Paulo, v. 52, n. 3, p. 234-248, 2015.

VALENÇA, S. R. F. A.; VALENÇA, R. M. B.; PINHEIRO-JUNIOR, J. W.; ALBUQUERQUE, P. P. F.; SOUZA NETO, O. L.; MOTA, R. A. Risk factors of occurrence of Toxoplasma gondii among horses in the state of Alagoas, Brazil. Acta Parasitologica, Oxford, v. 60, n. 4, p. 707-711, 2015.

VASCONCELLOS, S. A.; BARBARINI, O.; UMEHARA, O.; MORAIS, Z. M.; CORTEZ, A.; PINHEIRO, S. R.; FERREIRA NETO, J. S. Leptospirose bovina. Níveis de ocorrência e sorotipos predominantes em rebanhos dos Estados de Minas Gerais, São Paulo, Rio de Janeiro, Paraná, Rio Grande do Sul e Mato Grosso do Sul no período de janeiro a abril de 1996. Arquivos do Instituto Biológico, São Paulo, v. 64, n. 2, p. 7-15, 1997.
VASCONCELOS, C. G. C. Zoonoses ocupacionais: Inquérito soro-epidemiológico em estudantes de medicina veterinária e análise de risco para leptospirose, brucelose e toxoplasmose. 2003. Tese (Doutorado em Doenças Tropicais) - Faculdade de Medicina de Botucatu, Universidade Estadual Paulista-UNESP, Botucatu.

VENTURI, S. S.; SILVA, A. F.; TEIXEIRA, E. F.; OLIVEIRA, F. C.; CONSALTER, A.; PADILHA, F. G.; FONSECA, A. B.; FERREIRA, A. M. R. Characterization of the zoonotic potential of Toxoplasma gondii in horses from Rio de Janeiro State. Acta Tropica, Basel, v. 171, n. 1, p. 159-162, 2017.

WITKOWSKI, L.; CYWINSKA, A.; TRELA, K. P.; CRISMAN, M.; KITA, J. Multiple etiologies of equine recurrent uveitis - a natural model for human autoimmune uveitis: A brief review. Comparative Immunology, Microbiology and Infectious Diseases, Oxford, v. 44, n. 1, p. 14-20, 2016. 